\title{
PENGARUH PREFERENSI DAN PENGETAHUAN PRODUK TERHADAP MINAT MENABUNG MASYARAKAT PADA BANK NAGARI UNIT LAYANAN SYARIAH CABANG PASAR RAYA PADANG
}

\author{
Claudia Meidisa, Febsri Susanti \\ Sekolah Tinggi Ilmu Eknomi "KBP" \\ febsrisusanti@akbpstie.ac.id
}

\begin{abstract}
Syariah System in Civilization has take a place in Banking System beside the Konventional System. Bank Nagari already has a Syriah Unit System for their client but its target never filled. To make efforts to look for the problem, client interested needs to be done. Based On Most Reseach, Preference and Product Knowing is major variable to know about client favor and this research focuses on them . as a result of research efforts to improve the implementation of client favor to save in Syriah System.
\end{abstract}

Keywords: Syariah System, Preference, Product Knowing ,client Favor.

\section{Pendahuluan}

UU no 7 Tahun 1992 yang diamandemen menjadi UU BI no 10 Tahun 1998 tentang Perbankan Indonesia, Bank (Bank pemerintah maupun Bank swasta) menjalankan kegiatannya sesuai peraturan yang berlaku termasuk juga Produk bank yang banyak diminati yaitu pinjaman uang yang pembayarannya diansur dengan menambahkan bunga pada pinjaman tersebut yang nilainya disesuaikan dengan suku bunga pada saat melakukan pembayaran ansuran pinjaman.

Sistem Perbankan syariah menjadi salah satu alternatif bagi masyarakat yang tidak mau menabung di bank koventional dengan alasan riba dan tidak sesuai dengan syariat islami, maka kemunculan bank syariah di indonesia menjadi pendorong roda ekonomi yang menghimpun dari masyarakat sekaligus mensejahterakan masyarakat dengan sistem profit sharing sebagai salah satu akad dari ekonomi syariah.

Tabel 1

Perbedaan Bank Syariah dengan Konventional

\begin{tabular}{|c|c|c|}
\hline No & Bank Syariah & Bank Konventional \\
\hline 1 & Berdasarkan Prinsip Bagi Hasil & Berdasarkan tujuan Membungakan uang \\
\hline 2 & Menggunakan Prinsip Jual beli & Menggunakan prinsip pinjam meminjam \\
\hline 3 & $\begin{array}{l}\text { Hubungan dengan nasabah dalam bentuk } \\
\text { kemitraan }\end{array}$ & $\begin{array}{l}\text { Hubungan dengan nasabah dalam bentuk Kreditur- } \\
\text { Debitur }\end{array}$ \\
\hline 4 & $\begin{array}{l}\text { Melakukan investasi yang bersifat halal } \\
\text { menurut islam }\end{array}$ & $\begin{array}{l}\text { Melakukan investasi baik yang halal maupun yang } \\
\text { haram dalam islam }\end{array}$ \\
\hline 5 & $\begin{array}{l}\text { Setiap produk dan jasa yang diberikan } \\
\text { sesuai dengan fatwa dewan syariah }\end{array}$ & Tidak mengenal dewan sejenis seperti syariah \\
\hline 6 & $\begin{array}{l}\text { Ansuran Sesuai dengan akad yang } \\
\text { disepakati dari awal perjanjian }\end{array}$ & $\begin{array}{l}\text { Ansuran bersifat fluktuatif / sesuai dengan suku bunga } \\
\text { pada saat itu }\end{array}$ \\
\hline
\end{tabular}

Sumber: Muhammad Syafii Antonio (2001), Bank Syariah : Dari Teori ke Praktek (Gema Insani Press bekerja sama dengan Yayasan Tazkia Cendekia).

Pemerintah indonesia mengeluarkan UU no 21 tahun 2008 tentang Perbankan syariah, sebagai solusi dari masyarakat yang enggan menabung di bank bersifat 
konventional.Berdasarkan Undang-undang diatas, Perbankan Syariah adalah semua yang berkaitan dengan bank syariah dan unit layanan Syariah, mencakup kelembagaan, kegiatan usaha, serta cara dan proses dalam melaksanakan kegiatan usahanya sedangkan Bank Syariah adalah adalah Bank yang menjalankan kegiatan usahanya berdasarkan Prinsip Syariah.

Berdasarkan data pada tabel 1.2 dapat disimpulkan bahwa minat masyarakat menabung di tabungan dengan sistem konventional masih lebih tinggi dibandingkan dengan tabungan syariah pada Bank Nagari Cabang Pasar Raya.

\section{Tabel. 2}

Data Nasabah Bank Nagari Cabang Pasar Raya

Tahun 2015-2017

\begin{tabular}{|c|c|c|c|c|}
\hline \multirow{2}{*}{ No. } & Sistem & \multicolumn{3}{|c|}{ Tahun } \\
\cline { 3 - 5 } & Perbankan & $\mathbf{2 0 1 5}$ & $\mathbf{2 0 1 6}$ & $\mathbf{2 0 1 7}$ \\
\hline 1 & Konventional & 27.313 & 27.992 & 27.434 \\
\hline 2 & Syariah & 9.581 & 10.101 & 7.992 \\
\hline
\end{tabular}

Sumber : Data Bank Nagari Cabang Pasar Raya

Kurangnya minat masyarakat sumatera barat menabung di layanan syariah Bank Nagari dapat diketahui dari berberapa faktor, teori mengenai minat menabung di bank syariah dapat menjadi salah satu solusi untuk menaikkan Tren Performance Unit layanan Syariah Bank Nagari diantaranya teori yang dikemukakan oleh Kotler (2002) yang berpendapat bahwa Preferensi konsumen menunjukkan kesukaan terhadap pilihan produk dan jasa yang adakemudian berdasarkan penelitian yang dilakukan oleh Neng Kamarni, Preferensi dari bank syariah dapat berupa biaya tabungan, sistem bagi hasil/profit Sharing, informasi mengenai bank syariah, lokasi yang mudah dijangkau, pelayanan yang ramah bernuansa islami serta fasilitas ATM.

Faktor lain yang juga mempengaruhi minat menabung di Bank Syariah adalah pengetahuan mengenai produk dan jasa, Bank Syariah menempuh mekanisme bagi hasil sebagai pemenuhan kebutuhan permodalan dan melalui mekanisme jual-beli sebagai pemenuhan kebutuhan pembiayaa, dari pemenuhan permodalan yang ditawarkan tersebut, antara lain: pembiayaan Mudharabah, Murabahah, Musyarakah dan Qardul Hasan,dengan menggunakan sistem bagi hasil (Anonim, 1998: 2 ).

Berberapa penelitian yang dilakukan menunjukkan adanya hubungan antara preferensi dan pengetahuan produk dengan minat menabung di bank syariah diantaranya penelitian yang dilakukan oleh Neng Kamarni (2012) menunjukkan bahwa preferensi yang terdiri dari agama, status pekerjaan, tingkat pendidikan, pengetahuan tentang keberedaan bank syariah menjadi factor yang mempengaruhi minat menabung di bank syariah, kemudian penelitian selanjutnya yang dilakukan oleh Ardik Kristiawan (2011) menyatakan dalam penelitiannya alasan masyarakat memilih produk dari bank syariah yang secara langsung mempengaruhi minat orang menabbung di bank syariah.

Berdasarkan hal- hal yang tersebut diatas menjadi landasan masalah bagi penulis dalam melakukan penelitian dengan judul: "Pengaruh Preferensi dan Pengetahuan Produk Terhadap Minat Menabung Masyarakat PadaBankNagari Unit Layanan SyariahCabang Pasar Raya Padang“.

\section{Metode Penelitian}


Metode yang digunakan dalam penelitian ini adalah metode korelasi bersifat kolaborasi (mix) antara kualitatif dengan kuantitatif. Kasiram (2008:149), penelitian bersifat kuantitatif adalah suatu proses menemukan pengetahuan yang menggunakan data berupa angka sebagai alat menganalisis keterangan mengenai apa yang ingin diketahui. Sedangkan penelitian kualitatif adalah penelitian yang berlandaskan filsafat post positivisme yang digunakan untuk meneliti objek alamiah yang hasil penelitiannya lebih ditekankan kepada makna (Sugiyono, 2010:9). Populasi dalam penelitian ini adalah seluruh nasabah bank nagari unit layanan syariah pasar raya padang, dengan sampel berjumlah 100 orang.

Variabel yang digunakan dalam penelitian ini dibedakan menjadi dua kategori yaitu variabel bebas (independen) dan variabel terikat (dependen). Adapun yang termasuk dalam variabel bebas dalam penelitian ini adalah: Preferensi dan Pengetahuan Produk

Menurut Sugiyono (2012:4) variabel dependen adalah variabel yang dipengaruhi atau yang menjadi akibat, karena adanya variabel independen/bebas. Variabel terikat pada penelitian ini adalah Minat Menabung Nasabah pada Bank Nagari Unit Layanan Syariah Pasar Raya Padang.

Metode pengumpulan data adalah teknik atau cara-cara yang dapat digunakan oleh peneliti untuk mengumpulkan data. Jenis data yang dikumpulkan dalam penelitian ini adalah data primer. Pengumpulan data primer dilakukan dengan menyebarkan kuesioner, baik secara langsung maupun melalui email, kepada responden.

Tabel 3

Kisi Kisi Variabel Penelitian

\begin{tabular}{|c|c|c|c|}
\hline Variabel & Definisi & Indikator & Skala \\
\hline $\mathrm{Y}$ & $\begin{array}{l}\text { Minat dalam kamus besar bahasa } \\
\text { Indonesia diartikan sebagaisebuah } \\
\text { kecenderungan hati yang tinggi terhadap } \\
\text { sesuatu gairah atau keinginan. Minat } \\
\text { merupakan kecenderungan seseorang } \\
\text { untuk menentukan pilihan aktivitas. }\end{array}$ & $\begin{array}{l}\text { A. dorongan dari dalam } \\
\text { individu } \\
\text { B. motif sosial } \\
\text { C.Faktor emosional }\end{array}$ & $\begin{array}{l}\text { Skala Liker } \\
1-5\end{array}$ \\
\hline $\mathrm{X} 1$ & $\begin{array}{l}\text { Menurut Kamus Besar Bahasa Indonesia } \\
(2006) \text { Preferensi adalah pilihan, } \\
\text { kecenderungan, kesukaan atau hal yang } \\
\text { untuk didahulukan, diprioritaskan, dan } \\
\text { diutamakan daripada yang lain. Jadi } \\
\text { preferensi konsumen adalah } \\
\text { kecenderungan seseorang dalam memilih } \\
\text { penggunaan barang tertentu untuk dapat } \\
\text { dirasakan dan dinikmati sehingga dapat } \\
\text { mencapai kepuasan dari pemakaian } \\
\text { produk, pada akhirnya konsumen loyal } \\
\text { terhadap merk tertentu daripada produk } \\
\text { yang sejenis. }\end{array}$ & $\begin{array}{l}\text { A. Faktor lokasi } \\
\text { B. Faktor pelayanan } \\
\text { C. Faktor Profit } \\
\text { Sharing }\end{array}$ & $\begin{array}{l}\text { Skala Liker } \\
1-5\end{array}$ \\
\hline $\mathrm{X} 2$ & $\begin{array}{l}\text { Menurut Fandy Tjiptono ( } 1997: 95 \text { ) } \\
\text { menyatakan bahwa : } \\
\text { "Produk merupakan segala sesuatu yang } \\
\text { dapat ditawarkan produsen untuk } \\
\text { diperhatikan, diminta, dicari, dibeli, } \\
\text { digunakan, atau dikonsumsi pasar } \\
\text { sebagaipemenuhan kebutuhan atau } \\
\text { keinginan pasaryang bersangkutan". }\end{array}$ & $\begin{array}{l}\text { A. Mekanisme Produk } \\
\text { B. Iklan (promosi) }\end{array}$ & $\begin{array}{l}\text { Skala Liker } \\
1-5\end{array}$ \\
\hline
\end{tabular}

Kuesioner dalam penelitian ini terdiri dari tiga bagian yaitu Bagian I, berupa pertanyaan terbuka yaitu pertanyaan-pertanyaan mengenai identitas responden seperti nama 
responden, usia, jenis kelamin, pendidikan terakhir dan level hak akses (admin/operator). Bagian II, adalah pertanyaan-pertanyaan tertutup meliputi semua variabel penelitian. Bagian III adalah saran-saran bersifat solutif dan membangun.

Skala pengukuran dalam penelitian ini menggunakan skala Likert yang mempunyai 5 skala, yaitu 1-5. Ada dua jenis pernyataan yang akan diberikan dalam penelitian ini. Pertama pernyataan yang bernilai positif, untuk pernyataan ini akan diberi skor dari yang sangat positif sampai dengan yang sangat negatif. Kedua adalah pernyataan yang bernilai negatif, untuk pernyataan ini akan diberi skor dari yang sangat negatif sampai dengan yang sangat positif.

Uji validitas dan reliabilitas instrumen dilakukan sebelum menyebarkan kuesioner kepada responden penelitian dengan menggunakan SPSS. Hasil uji validitas dan reliabilitas menunjukkan bahwa dari 29 butir pernyataan pada kuesioner, sebanyak 3 butir pernyataan dinyatakan tidak valid dan harus digugurkan. Selanjutnya kuesioner yang digunakan dalam penelitian terdiri atas 26 butir pernyataan.

Teknik analisis data yang digunakan dalam penelitian ini adalah menggunakan metode Analisis regresi berganda. Software statistik yang digunakan dalam penelitian ini adalah SPSS 16.

Melakukan analisis data dengan menggunakan regresi berganda, terdapat minimal tiga uji prasyarat yang harus dilakukan. Pertama, normalitas data; kedua, melakukan uji Multikolineritas, dan uji Heterokedastisitas.

1. Uji Normalitas Data

Uji normalitas data bertujuan untuk menguji apakah dalam model regresi, variabel dependen maupun independen mempunyai distribusi normal atau tidak. Model regresi yang baik adalah yang memiliki distribusi normal atau mendekati normal (Imam Ghozali, 2005).

2. Uji Multikolinieritas

Tujuan dari uji multikolinieritas adalah untuk menguji adanya korelasi antar variabel independen. Model regresi yang baik seharusnya tidak terjadi korelasi di antara variabel independen. Jika variabel independen saling berkorelasi, maka variabel-variabel ini tidak ortogonal. Variabel ortogonal adalah variabel independen sama dengan nol.

Untuk mendeteksi ada atau tidaknya multikolinieritas di dalam model regresi adalah dengan cara melihat nilai variance inflation factor (VIF). Jika nilai VIF lebih besar dari 10, maka terjadi multikolinieritas.

3. Uji Heteroskedastisitas

Uji ini bertujuan untuk melihat apakah dalam model regresi terjadi ketidak samaan variance dari residual satu pengamatan ke pengamatan lain. Jika variance dari residual satu pengamatan ke pengamatan lain tetap, maka disebut homoskedastisitas. Model inilah yang diharapkan terjadi. Jika variance dari residual satu pengamatan ke pengamatan lainnya berbeda, maka terjadi heteroskedastisitas (Ghozali, 2005).

Untuk menguji apakah dalam model regresi terjadi heteroskedastisitas atau tidak, penelitian ini menggunakan cara yaitu dengan melihat grafik plot antara nilai prediksi variabel dependen.

Uji heteroskedastisitas dengan cara melihat grafik plot antara nilai prediksi variabel bebas, yaitu ZPRED dengan residualnya SRESID. Deteksi ada tidaknya heteroskedastisitas dapat dilakukan dengan melihat ada tidaknya pola tertentu pada grafik 
scatterplot antara SRESID dan ZPRED di mana sumbu Y adalah Y yang telah diprediksi, dan sumbu $\mathrm{X}$ adalah residual (Y prediksi-Y sesungguhnya) yang telah di-studentized.

\section{Hasil dan Pembahasan}

\section{Pengujian Persyaratan Regresi}

a. Uji Normalitas Data

Taraf signifikansi yang digunakan sebagai dasar menolak atau menerima keputusan normal atau tidak suatu distribusi data adalah 0,05. Hipotesis yang dibentuk untuk uji normalitas adalah jika nilai Asymp.Sig > signifikansi alpha 0,05 maka data berdistribusi normal, dapat dilihat pada tes Kolmogorov Smirnov diatas nilai Asymp.Sig 0,200 > Aplha 0,05 maka dikatakan data berdistribusi normal. Sebaliknya jika nilai Asymp.Sig $<$ signifikasnsi alpha 0,05 maka data tidak bedistribusi normal.

Tabel 4

Hasil Uji Normalitas Data dengan Kolmogorov Smirnov One-Sample Kolmogorov-Smirnov Test

\begin{tabular}{|c|c|c|c|c|}
\hline & & PREFERENSI & PENGETAHUAN & MINAT \\
\hline $\mathrm{N}$ & & 100 & 100 & 100 \\
\hline \multirow[t]{2}{*}{ Normal Parameters ${ }^{\mathrm{a}}$} & Mean & 41.42 & 27.81 & 31.97 \\
\hline & $\begin{array}{l}\text { Std. } \\
\text { Deviation }\end{array}$ & 5.182 & 3.501 & 5.038 \\
\hline \multirow[t]{3}{*}{ Most Extreme Differences } & Absolute & .092 & .118 & .086 \\
\hline & Positive & .065 & .118 & .086 \\
\hline & Negative & -.092 & -.112 & -.078 \\
\hline Kolmogorov-SmirnovZ & & .920 & 1.184 & .863 \\
\hline Asymp. Sig. (2-tailed) & & .365 & .121 & .445 \\
\hline \multicolumn{2}{|c|}{ a. Test distribution is Normal. } & & & \\
\hline
\end{tabular}

b. Uji Multikolineritas

Gejala multikolinieritas dapat diketahui melalui suatu uji yang dapat mendeteksi dan menguji apakah persamaan yang dibentuk terjadi gejala multikolinieritas, dengan menggunakan atau korelasi di antara variabel bebas, caranya adalah dengan melihat masing-masing hubungan variabel bebas terhadap variabel bebas lainnya, dengan melihat Tabel interprestasi koefisien korelasi. Metode untuk menguji adanya multikolinieritas dilihat pada Variance Inflation Factor (VIF). Batas dari VIF adalah kecil dari 10.

Berdasarkan Tabel hasil analisis multikolinearitas tidak terdapat multikolinearitas antara masing-masing variabel independen dalam model regresi, karena nilai toleransi masing-masing variabel lebih besar dari 0,10 yaitu 0,624 (X1), 0,624 (X2), dan nilai VIF lebih kecil dari 10,00 yaitu 1,602 (X1), 1,602 (X2). 


\section{Uji Multikolinearitas Variabel Penelitian}

\begin{tabular}{|c|c|c|c|c|c|c|c|c|}
\hline \multicolumn{9}{|c|}{ Coefficients $^{a}$} \\
\hline & & Unstandardized & Coefficients & $\begin{array}{l}\text { Standardized } \\
\text { Coefficients }\end{array}$ & & & Collinearity $\varsigma$ & atistics \\
\hline \multicolumn{2}{|c|}{ Model } & B & Std. Error & Beta & $t$ & Sig. & Tolerance & VIF \\
\hline \multirow[t]{3}{*}{1} & (Constant) & 14.910 & 3.918 & & 3.805 & .000 & & \\
\hline & PREFERENSI & -.170 & .107 & -.175 & -1.586 & .116 & .624 & 1.602 \\
\hline & PENGETAHUAN & .867 & .159 & .602 & 5.463 & .000 & .624 & 1.602 \\
\hline
\end{tabular}

\section{c. Uji Heterokedastisitas}

Model regresi yang baik adalah yang bersifat homokedastisitas atau tidak terjadi heteroskedastisitas. Uji heterokedastisitas dalam penelitian ini diuji dengan scaterplots dengan bantuan software SPSS versi 16.

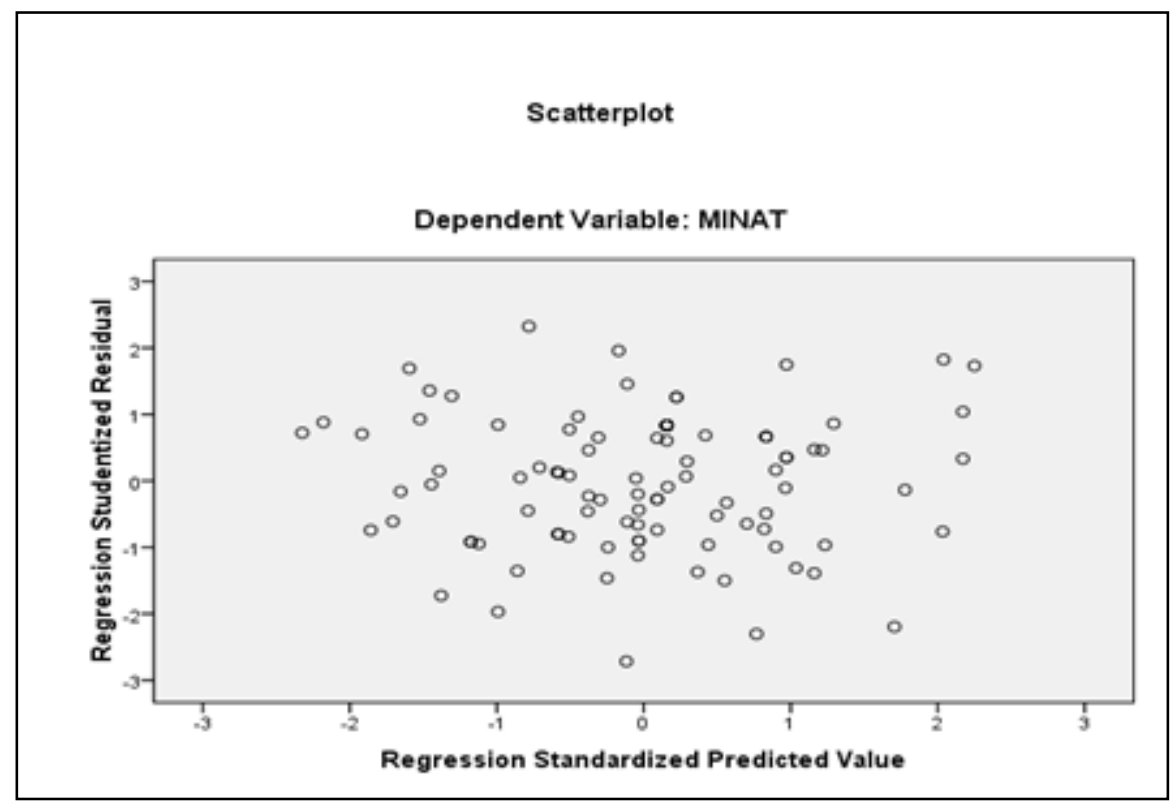

Gambar Scatterplot Heterokedastisitas Variabel Penelitian

Hasil uji heteroskedastisitas menunjukkan bahwa titik-titik tersebar diatas dan dibawa angka nol. Titik-titik menyebar dan tidak membentuk pola tertentu yang teratur sehingga dapat disimpulkan bahwa dalam model regresi tidak terjadi homokedastisitas.

\section{Pengujian Asumsi Penelitian}

\section{Uji Regresi Berganda}

Menguji hipotesis yang telah dirumuskan, digunakan uji statistik dengan teknik korelasi dan regresi. Teknik korelasi dan regresi berganda digunakan untuk menguji hipotesis pertama dan kedua. Pengujian hipotesis digunakan program SPSS 16. Pengujian dilakukan dengan analisis dua arah (two-tailed) yang berguna untuk 
menentukan arah tingkat hubungan yang belum diketahui, yaitu tingkat hubungan positif dan tingkat hubungan negatif. Hasil analisis korelasi kedua variabel bebas preferensi (X1), pengetahuan (X2) terhadap variabel minat menabung (Y) disajikan sebagai berikut:

\section{Tabel 6}

\section{Hasil Uji Korelasi Variabel Penelitian $X_{1}$ dan $x 2$ dengan $Y$}

\begin{tabular}{|c|c|c|c|c|c|c|c|c|}
\hline \multicolumn{9}{|c|}{ Coefficients $^{\mathrm{a}}$} \\
\hline \multirow[b]{2}{*}{ Model } & & \multicolumn{2}{|c|}{$\begin{array}{l}\text { Unstandardized } \\
\text { Coefficients }\end{array}$} & \multirow{2}{*}{\begin{tabular}{|c|}
$\begin{array}{c}\text { Standardized } \\
\text { Coeff icients }\end{array}$ \\
Beta
\end{tabular}} & \multirow[b]{2}{*}{$t$} & \multirow[b]{2}{*}{ Sig. } & \multicolumn{2}{|c|}{ Collinearity Statistics } \\
\hline & & $B$ & Std. Error & & & & Iolerance & VII \\
\hline \multirow[t]{3}{*}{1} & (Constant) & 14.910 & 3.918 & & 3.805 & .000 & & \\
\hline & Pref erensi & -.170 & .107 & -.175 & -1.586 & .116 & .624 & 1.602 \\
\hline & Produk & .867 & 159 & 602 & 5.463 & .000 & .624 & 1.602 \\
\hline
\end{tabular}

\section{Hipotesis Pertama (Uji t X1)}

Dari hasil pengujian hipotesis pertama, maka:

"antara preferensi berpengaruh positif dan signifikan terhadap minat menabung. Pengujian hipotesis ini dilakukan untuk mengetahui ada tidaknya korelasi/hubungan variabel preferensi $\left(\mathrm{X}_{1}\right)$ terhadap minat menabung (Y) seperti terlihat pada Tabel 2.1

Nilai Signifikansi Tabel 4.12 x1 adalah 0,116 yang nilainya lebih besar dari 0,05 yang berarti tidak signifikansi $(p>0,05)$. Hasil tersebut menunjukkan bahwa koefisien regresi variabel $\mathrm{X} 1$ tidak signifikan dalam persamaan $\mathrm{Y}=$ 14.910 - 0,170X1. Artinya variabel X1 tidak dapat menjelaskan minat secara signifikan.

\section{Hipotesis Kedua (Uji t X2)}

Hipotesis kedua yang diajukan dalam penelitian ini adalah: "antara pengetahuan produk berpengaruh positif dan signifikan terhadap minat". Pengujian hipotesis ini dilakukan untuk mengetahui ada tidaknya hubungan variabel pengetahuan produk $\left(\mathrm{X}_{2}\right)$ terhadap variabel minat $(\mathrm{Y})$ seperti terlihat pada Tabel 2.1 .

Nilai Signifikansi $\mathrm{x} 2$ adalah 0,000 yang nilainya lebih kecil dari 0,05 yang berarti signifikansi $(\mathrm{p}<0,05)$. Hasil tersebut menunjukkan bahwa koefisien regresi variabel $\mathrm{X} 2$ signifikan dalam persamaan $\mathrm{Y}=14.910+0,867 \mathrm{X} 2$. Artinya variabel X2 dapat menggambarkan hubungan antara preferensi dengan minat.

\section{Uji Simultan (Uji) F}

Tabel 7

Hasil Analisis Regresi Variabel Penelitian $X_{1}$ dan $x 2$ dgn $Y$

\begin{tabular}{|ll|r|r|r|r|r|}
\hline Model & & Sum ot Squares & dt & Mean Square & \multicolumn{1}{|c|}{ ' } & \multicolumn{1}{c|}{ Sig. } \\
\hline 1 & Regression & 663.782 & 2 & 331.891 & 17.410 & $.000^{\circ}$ \\
& Residual & 1849.128 & 97 & 19.063 & & \\
& Total & 2512.910 & 99 & & & \\
\hline B & & & & \\
&
\end{tabular}


erdasarkan Tabel di atas dapat diketahui bahwa $\mathrm{F}$ hitung $=17.410>\mathrm{F}$ Tabel $=3.090$ dengan nilai Sig $0,000<0,05$, hal ini menandakan model atau persamaan regresi yang dibuat baik atau signifikan.

Berdasarkan Tabel 2.2. di atas dapat diketahui bahwa $\mathrm{F}$ hitung $=17.410>\mathrm{F}$ Tabel $=3.090$ dengan nilai Sig $0,000<0,05$, hal ini menandakan model atau persamaan regresi h1 diterima dan signifikan.

\section{Uji Determinasi (R2)}

Koefisien determinasi $\left(\mathrm{R}^{2}\right)$ pada tabel bernilai 0,264 artinya variabel preferensi dan, pengetahuan produk secara simultan mampu menjelaskan variabel minat menabung sebesar $26,4 \%$ sedangkan sisanya ditentukan oleh faktor lain.

\section{Tabel 8}

\section{Hasil Uji Determinasi $X_{1}$ dan $x 2$ dgn $Y$}

Model Summary

\begin{tabular}{|l|r|r|r|r|}
\hline Model & \multicolumn{1}{|c|}{ R } & R Square & \multicolumn{1}{|c|}{ Adjusted R Square } & \multicolumn{1}{c|}{ Std. Error of the Estimate } \\
\hline 1 & $.514^{2}$ & .264 & .249 & 4.366 \\
\hline
\end{tabular}

\section{Pembahasan}

Nilai Signifikansi x1 adalah 0,116 yang nilainya lebih besar dari 0,05 yang berarti tidak signifikansi $(\mathrm{p}>0,05)$. Hasil tersebut menunjukkan bahwa koefisien regresi variabel X1 tidak signifikan.

Nilai Signifikansi Tabel 4.11 adalah 0,000 yang nilainya lebih kecil dari 0,05 yang berarti signifikansi $(\mathrm{p}<0,05)$. Hasil tersebut menunjukkan bahwa koefisien regresi variabel $\mathrm{X} 2$ signifikan.

\section{Kesimpulan dan Saran}

\section{Kesimpulan}

Berdasarkan analisis terhadap data penelitian seperti yang telah dipaparkan pada bab sebelumnya. Beberapa kesimpulan dalam penelitian ini antara lain:

1. Terdapat hubungan yang tidak signifikan antara Preferensi $\left(\mathrm{X}_{1}\right)$ dengan Minat Menabung (Y) Artinya semakin tinggi Preferensi, maka tidak berpengaruh terhadap minat menabung. Persamaan regresinya $\mathrm{Y}=14.910-0,170 \mathrm{X} 1$.

2. Terdapat hubungan yang signifikan antara Pengetahuan Produk $\left(\mathrm{X}_{2}\right)$ dengan kinerja (Y) Artinya semakin tinggi Pengetahuan Produk, maka Minat Mebanung akan semakin tinggi. Persamaan regresinya $\mathrm{Y}=14.910+0,867 \mathrm{X} 2$

\section{Saran}

Berdasarkan kesimpulan yang telah dikemukakan termasuk pembahasan hasil analisis penelitian, maka berikut ini beberapa saran dari penelitian ini antara lain:

1. Stakeholder sebaiknya memperhatikan Pengetahuan Produk di Bank Nagari Pasar Raya Padang Unit Layanan Syariah karena faktor ini memberikan pengaruh Minat Menabungyang merupakan hal positif bagi Bank

2. Perlunya penelitian lebih lanjut mengenai faktor lain yang mempengaruhi Minat Menabungselain faktor Preferensi dan Pengetahuan Produk. 
3. Peneliti menyadari adanya beberapa kelemahan dalam penelitian ini yang terkait dengan keterbatasan penelitian. Saran bagi peneliti yang mengambil penelitian ini sebagai pembanding atau mengambil tema sejenis untuk adanya tambahan beberapa variabel yang mungkin dapat meningkatkan Minat Menabung Masyarakat.

\section{DAFTAR PUSTAKA}

Abdullah, Wasilah., Firdaus A. Dunia. 2011. Akuntansi Biaya. Edisi kedua. Jakarta ; Salemba Empat.

Fernandes, Y. D., \& Marlius, D. (2018). Peranan Customer Service Dalam Meningkatkan Pelayanan Kepada Nasabah Pada PT. Bank Pembangunan Daerah Sumatera Barat Cabang Utama Padang. https://doi.org/10.31227/osf.io/wrh3p

Ghozali, Imam. 2005. Aplikasi Analisis Multivariate dengan Program SPSS. Semarang : Undip

Kasmir. 2014. Bank dan Lembaga Keuangan lainnya. Jakarta; Raja Grafindo Persada.

Marlius, D. (2016). Pengaruh Bauran Pemasaran Jasa Terhadap Minat Nasabah Dalam Menabung Pada Bank Nagari Cabang Muaralabuh. https://oi.org/10.31227/osf.io/vdqgx

Marlius, D. (2018). Loyalitas Nasabah Bank Nagari Syariah Cabang Bukittinggi Dilihat Dari Kualitas Pelayanan. Jurnal Pundi. Volume 1. No. 3. Hal.12-22. https://doi.org/10.31575/jp.v1 i3.60

Peraturan Bank Indonesia Wilayah Padang no 8/1/DPbs/PIA (https://id.wikipedia.org/wiki/Bank_Nagari_Syariah, online, diakses tanggal 08 Juli 2017).

Perbedaan Perbankan syariah dengan Konventional (www.ekonomi-islam.com, online, diakses tanggal 10 Juni 2017).

Priyanti,Y. Susanti, F. Aziz, N. (2017). Minat Beli Konsumen Toko Sepatu Bata Dipasar Raya Padang Dilihat Dari Sikap Dan Iklan. Jurnal Pundi, Vol. 01, No. 02

Susilo, Sri, Dkk. 2000. Bank dan Lembaga Keuangan lain. Jakarta; Salemba Empat.

Surat Keputusan Pemimpin Cabang Pasar Raya Padang. 2017. Trend Performance Office Chanelling Syariah Cabang Pasar Raya Padang.

Sukanto M.M. 1985. Nafsiologi. Jakarta; Integritas Press.

Undang-undang BI no 10 Tahun 1998 tentang Perbankan ( http $/ /$ www.bi.go.id/id/tentang-bi/uubi, online, diakses tanggal 10 Juni 2017). 